\title{
The Effect of Entrepreneurial Orientation on Competitive Advantages of Selected SMEs' in Lagos, Nigeria
}

\author{
Olowofeso, Edamisan (Ph.D) \\ Department of Entrepreneurship, The Federal University of Technology, Akure, Nigeria
}

\begin{abstract}
In a dynamic business environment, investors must develop a plan to gain a competitive edge over their rivals. The effect of EO-dimensions on the competitive advantages of selected SMEs in Lagos, Nigeria was investigated in this study. The population of the study comprised both small and medium enterprises (SME) in Lagos State, Nigeria. Eight sectors of SMEs were established for the study, and sixty (60) SMEs were selected randomly from each of these sectors, with a total sample size of four hundred and eighty (480) SMEs. Using a simple random sampling method, questionnaires were distributed to the 480 SMEs, considered as a sample size for the study, from which three hundred and ninety-two (392) copies were retrieved for analysis. The data were analyzed using SPSS version 25. Multiple regression analysis was used to examine the effect of each of the EO-dimensions on the competitive advantages of the SMEs. The results of the study revealed that three EO-dimensions (innovativeness, proactiveness, and autonomy) are associated with SMEs' competitive advantage. The study recommended that those variables that lead to an improvement in the competitive advantages of the business should be made the focal points of the business strategies.
\end{abstract}

Keywords: Entrepreneurial orientation, competitive advantages, Lagos State, small and medium enterprises DOI: $10.7176 / \mathrm{JESD} / 12-22-06$

Publication date: November $30^{\text {th }} 2021$

\section{Introduction}

The importance of small and medium enterprises (SME) in the global economy cannot be overemphasised. It contributes greatly to economic development by providing jobs, generating wealth, and alleviating poverty (Masika, 2010; Hoque \& Awang, 2016; Mohammed \& Rusinah, 2017). Its contributions to the Nigerian Gross Domestic Product (GDP) was also significant (National Bureau of Statistics, 2015). Despite these advantages, SMEs' performances are not without some limitations such as pressure from other competitions, improper marketing strategy, lack of finance, inappropriate entrepreneurial behavior, strategic planning and weak relationship with customers (Bangudu, 2013; Alauddin \& Chowdhury, 2015; Hoque, Siddiqui, Awang \& Baharu, 2018). Obaji and Olugu (2014) observed that better SME success is based on a corporate culture, enabling strategies, and an entrepreneurship policy that can propel and grow a country's SME market. Any company's sustainability is dependent on its entrepreneurial behaviors (Lyon, Lumpkin \& Dess, 2000). The entrepreneur is in charge of the company's long-term viability and expansion. Most SMEs are unable to survive due to a shortage of funding and skills. SMEs with greater adaptability to change and versatility in their activities have a better chance of profiting from sudden improvements and discoveries (Ong et al., 2010).

Entrepreneurial orientation (EO) is a technique that has received a lot of support from academics in both developing and developed countries (Miller, 2011; Olubiyi, Egwakhe, Amos \& Ajayi, 2019; Olowofeso, 2021). EO is a strategy-making mechanism that gives companies a framework for making business choices and taking action. It is identified as a key predictor for organisational success as well as a factor that leads to higher performance (Covin \& Wales, 2012; Adams, Bodas \& Fontana, 2019; Olubiyi, Egwakhe, Amos \& Ajayi, 2019; Olowofeso, 2021). Wiklund and Shepherd (2005), Hughes and Meran, (2007), Li, Huang and Tsai (2009), Covin and Wales (2012) and Kusumawardhani (2013) noted that innovativeness, proactiveness, competitive aggressiveness, risk-taking, and autonomy are the five dimensions of EO. The effect of each of the EO-dimensions on the competitive advantages of SMEs in Nigeria was explored in this study. The bulk of EO study has been conducted in developed countries, according to Wales, Gupta, and Mousa (2011) and Mohammed and Rusinah (2017), and performance indicators like competitiveness, market share, competitive advantages, and workforce turnover were used. To the best of the researcher's knowledge, just a few studies have empirically evaluated the effect of EO on SME competitive advantages in developing countries, such as Nigeria. As a consequence, further studies in developing countries are needed. As a result, the goal of this study is to fill a research gap and show future research directions on SMEs in Lagos, Nigeria.

\section{Literature Review}

Small and medium enterprises (SME)

The definition of an SME varies by region (Gunasekaran, Forker \& Kobu, 2000). SME concepts are typically extracted in each country based on their economic positions, strategies, and programs developed by specific agencies or organisations tasked with SME development. What is considered a small business in developed 
countries can vary from what is considered a small business in developing countries. A small-scale business in a developed country like Japan may be a medium or large-scale business in a developing country like Nigeria (Etuk, Etuk \& Baghebo, 2014). Assets, business turnover, available financing, number of workers, resources hired, market share, and relative size within the sector are all metrics that can be used to describe an SME in any nation (Etuk et al., 2014). A small-scale business in Nigeria, according to Effiom and Edet (2018), is one with 11 to 100 employees and a budget of less than N50 million, including working capital excluding the land costs. A mediumsized business has a population of 101 to 300 people and a budget of N50 million to N200 million, inclusive of working capital but excluding property costs. The Central Bank of Nigeria (CBN) (2010) agreed on the number of employees listed above, but disagreed on asset valuation. Companies with assets ranging from N5 million to N500 million are listed as small and medium-sized enterprises (SMEs). SMEs are believed to account for about $40 \%$ of Nigeria's GDP and 70\% of manufacturing employment (Eniola, 2014). According to Duke (2006), small businesses account for $87 \%$ of all corporations in Nigeria, contributing $61 \%$ to GDP. They are responsible for 58\% of the US population. SME also contributes to the diversification of the national economy and the development of foreign currency, the growth of indigenous manufacturing and the utilization of local resources, poverty reduction, and income redistribution, in addition to the country's GDP and providing employment opportunities.

\section{Entrepreneurial orientation (EO)}

EO has been extensively researched in the field of management sciences, especially in the field of entrepreneurship, over the last three decades and it has received a lot of recognition, both conceptually and empirically. In the industry literature, it is a field of rapidly developing awareness (Covin \& Wales, 2012; Covin \& Miller, 2014). It has also been considered a valid concept in the field of entrepreneurship. It refers to the personal psychological traits, methods, strategy and decision-making styles that managers use to act entrepreneurially (Kemelgor, 2002; Kreiser, Marino \& Wearver, 2002). EO represents a perspective and frame of mind about entrepreneurship that is reflected in a firm's ongoing processes and corporate culture (Dess \& Lumpkin, 2005). According to Yamada and Eshima (2009) and Covin and Wales (2012), EO is a determining factor in the development and sustainability management of a business and is suggested as a key for success and higher performance. Various factors enhance the successful implementation of EO in any business, these factors include financial, social and economic factors of a business. The EO-dimensions are considered the building blocks for entrepreneurs and they explain methods, practices, and decision-making styles that managers or owners use for creating new ventures successfully and running existing ventures in a way to achieve success (Rauch, Wiklund, Lumpkin \& Frese, 2009).

EO is a term that refers to a company's overall approach and strategic decision-making (Lumpkin \& Dess, 1996). The willingness of an organisation to partake in creative activities, take risks, and enact new ideas is referred to as EO. On the other hand, Fauzul, Takenouchi and Yukiko (2010), Patel and D'Souza (2009) and Ellis (2011) describe EO as a decision-making process that determines a company's ability to innovate, be more aggressive and reactive than its competitors, and take calculated risks. According to Miller (1983), the philosophical paradigm of entrepreneurship as a firm's behavior has been a significant development. EO is a combination of innovation, pro-activeness and risk-taking. He suggests that an entrepreneurial firm is one that "engages in a new product, process and market innovation, beating competitors to the punch (Miller, 1983). The use of innovation, pro-activeness and risk-taking was also advocated as the key dimensions of entrepreneurship by Covin and Slevin (1991) and they refer to these as entrepreneurial posture. Covin and Slevin (1991) believe that firms with such entrepreneurial postures "are willing to innovate, take on high-risk projects with chances of very high returns, and are bold and aggressive in pursuing opportunities". Wiklund (1998) discovered that EO and entrepreneurial behavior are inextricably linked. As a result, an organisation with EO may be classified as an entrepreneurial one (Covin \& Wales, 2012). Proactivity in finding new growth prospects, risk-taking ability, and innovativeness have all been used in the past to determine a company's EO (Kreiser et al., 2002; Kropp et al., 2006). A reasonably stable collection of similar practices has been identified by many scholars (Wiklund \& Shepherd, 2003). EO represents "the organisational structures, strategies, and styles that companies employ to function entrepreneurially" which covers a wide variety of activities, such as a company's strategic decisionmaking styles and business practices (Lumpkin \& Dess, 1996). EO is a concept that refers to particular interpersonal activity that acts as a base for entrepreneurial conduct (Rauch et al., 2009; Covin \& Wales, 2012). Previous research has indicated that EO is a critical component of corporate effectiveness (Wiklund \& Shepherd, 2005; Covin \& Slevin, 1989) and a means of competitive advantage (Covin \& Slevin 1989; Wiklund \& Shepherd, 2005; Runyan, Droge, \& Swinney, 2008). Many studies have shown that firms with higher levels of EO do better than those with lower levels of EO (Lumpkin \& Dess 1996; Rauch et al., 2009).

\section{Competitive advantages of SMEs}

A company must achieve an edge over its rivals to make a profit in order to thrive. Firms achieve comparative benefits by outperforming their rivals in delivering unique market items to their consumers (Bateman \& Snell, 2004). The term "competitive advantage" has been described in a variety of ways. For instance, Porter (1985) avers 
that a competitive advantages refers to the competitive positional superiority in the marketplace that leads a firm to outperform its rivals. While Rothaermel (2013) defines competitive advantages as a company's design and implementation of a strategy that leads to greater performance than its competitors in the same market. Competitive advantages may also be described as the product of a company's strategic planning process in order to provide customers with additional value (differentiation and low cost), resulting in a temporary competitive advantage over competitors (Mohammed \& Rusinah, 2017). As a result, competitive advantage is described as an organisation's ability to offer greater value to its customers than its rivals, thus obtaining an advantage (Thompson, 2001).

\section{Entrepreneurial orientation and competitive advantages of SMEs.}

EO is the starting point for creating and implementing competitive strategies. Hence, studying EO and competitive strategy is a promising research endeavour (Rauch et al., 2009; Wales et al., 2011; Lechner \& Gudmundsson, 2014). EO has emerged as a potential solution to the difficulties that businesses face in retaining a long-term competitive advantage (Van- Geenhuizen, Middel \& Lassen, 2008). As a result, there is a strong desire to broaden one's understanding of EO from a business perspective. Different aspects of EO, for example, have different impacts on strategic advantages (innovativeness, proactiveness, and risk-taking) (Lechner \& Gudmundsson, 2014). In the innovation process, companies search for new ways to operate more efficiently. Business creativity aids a company's ability to work more efficiently by aiding it in finding ways that it can grow in the emerging market environment. (Kuratko, Ireland \& Hornsby, 2001). Diversity necessitates the opportunity to invent, culminating in innovative goods that bring value to the consumer and justify market premiums (Lechner \& Gudmundsson, 2014). In the same way, Gitau, Mukulu, and Kihoro (2016) claim that a company's success depends on its ability to bring innovative and rapid innovation to its consumers. As a result, increased innovativeness would increase SMEs' strategic advantages. As a result, the following hypothesis was proposed:

$\mathrm{H}_{01} \quad$ There is no significant effect of innovativeness on the competitive advantages of SMEs.

Firms who are pro-active in the industry respond to business opportunities by seizing the initiative (Li, Huang \& Tsai, 2009). It may be argued that proactive businesses seek out new and valuable resources to boost their strategic advantages at this stage in tracing the partnership between EO and resource procurement (Huang \& Wang, 2011). Firms with a higher EO will collaborate with the environment to access services on a positive basis. These energies will then be put to use on proactive and creative ventures, helping the organisation to discover and build on the ample possibilities that come with a lush environment. Firms can also pool creative tools to maximize their capacity to invest in such opportunities. As a result, they are more likely to gain a strategic edge and perform well (Rosenbusch, Rauch \& Bausch 2013). Small businesses must be proactive in finding and leveraging market opportunities (Gitau et al., 2016). The pro-activeness factor allows an organisation to perform continuous environmental scanning and predict transition in order to best represent consumers and markets. Pro-activeness takes advantage of a company's capacity to react to changing situations and the willingness to act (Hughes \& Morgan, 2007). As a result, a strategic company is most likely to be the first to market, and it is compensated with comparative advantages in the marketplace. Unusual returns, sales networks, and market awareness are only a few examples (Li et al., 2009). This leads to the following hypothesis:

$\mathrm{H}_{02} \quad$ There is no significant effect of pro-activeness on the competitive advantages of SMEs.

A proclivity for taking risky steps such as joining unfamiliar new markets, spending a considerable portion of one's resources in uncertain ventures, and/or borrowing heavily is characterized as risk-taking (Walter, Auer \& Ritter, 2006; Li, et al., 2009). It entails the ability to invest substantial capital in prospects that may collapse (Frese, Brantjes \& Hoorn, 2002). Risk-taking is largely a reflection of the organisation's ability to depart from the triedand-true in order to explore new territory (Wiklund \& Shepherd, 2003). It also helps business owners to make successful transactions, because it is linked to growth (Frese et al., 2002). Differentiation strategies include investing resources on research and growth, marketing new products and services, and developing a brand name (Porter, 1990). Furthermore, by seizing growth prospects, an organisation with significant capital investments can earn strong returns (Lumpkin \& Dess, 1996). As a result, risk-taking should be prioritized in a small business in order to gain a competitive advantage. EO is also a powerful capability that gives the company a long-term competitive advantage as well as increased performance. According to the firm's resource-based theory, a comparative edge may only be gained through using limited, intangible, and firm-specific assets. According to Tovstiga and Tulugurova (2009), the internal capital base of small and medium-sized companies is a determining factor of competitive advantage. The literature has shown that a firm's entrepreneurial behavior has a significant impact on its competitive advantage and productivity (Wiklund \& Shepherd; 2003). As a result, the following hypothesis was developed:

$\mathrm{H}_{03} \quad$ There is no significant effect of risk-taking on the competitive advantages of SMEs.

Competitive aggressiveness is described as "a firm's proclivity to specifically and intensely threaten its competitors in order to gain entrance or boost position in the marketplace, that is, to outperform industry rivals" (Lumpkin \& Dess, 1996). Aggressive companies are thought to be able to deal with their market competitors and remain in 
business. Researchers who have integrated this aspect into their EO approach have discovered that it has a positive impact on market performance in terms of innovation (Olowofeso, 2021). Casillas and Moreno (2010) found no connection between competitive aggressiveness and growth due to the dual-conditioning of active and passive competitive aggressiveness. Hughes and Morgan (2007) came up with a similar finding, the contradictory findings showed that the impact of competitive aggressiveness on firm success should be re-examined. Hence, the hypothesis was suggested as below:

$\mathrm{H}_{04}$ There is no significant effect of competitive aggressiveness on the competitive advantages of SMEs.

Autonomy, according to Lumpkin and Dess (1996), is the "independent behavior of a person or a group in putting forward a concept or a vision and seeing it forward to completion." Awang et al., (2009) verified the important positive relationship between autonomy and competitive advantages of firm. Casillas and Moreno (2010) and Hughes and Morgan (2010), on the other hand, found no evidence of such a connection. Previous researchers' mixed findings demonstrate the need for more study into the relationship between autonomy and firm success. Thus, the following hypothesis was suggested:

$\mathrm{H}_{05} \quad$ There is no significant effect of autonomy on the competitive advantages of SMEs.

\section{Conceptual framework and Hypothesis formulated}

The conceptual model proposed in this study illustrated in Figure 1 explains the relationship between innovativeness, pro-activeness, competitive aggressiveness, risk-taking, autonomy and competitive advantages of the firms. Figure 1 presents the constructs and the hypothesized relationships.

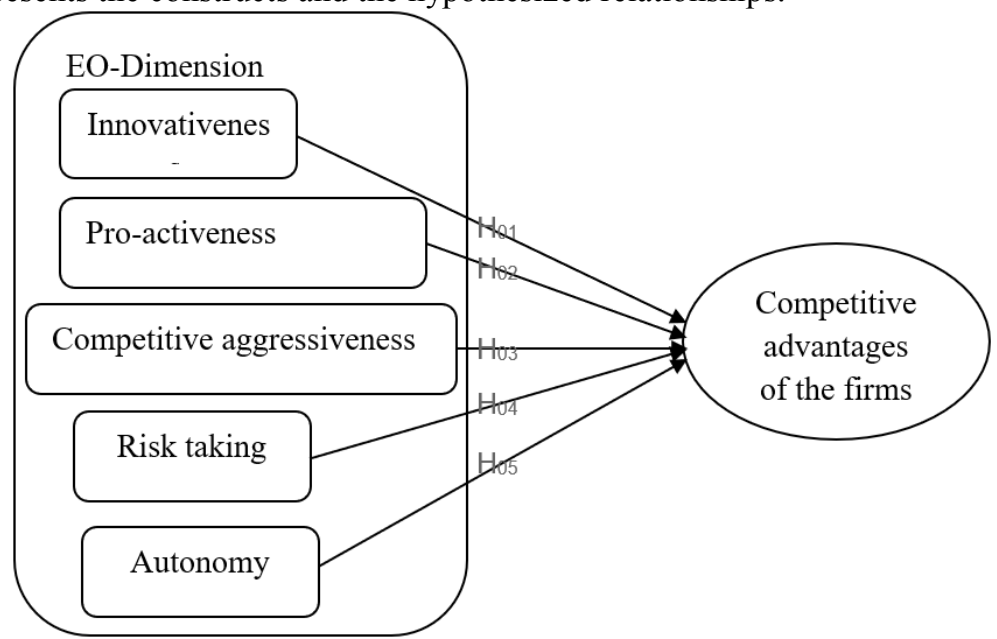

Figure 1: Conceptual framework showing the relationships between the EO-dimensions and competitive advantages of the firms.

Source: Author's conception based on the literature reviewed.

\section{Methodology}

The study's target population consisted of all the four thousand five hundred and thirty-five $(4,535)$ SME owners/managers who have registered with Nigeria's Small and Medium Business Development Agency (SMEDAN) in Lagos State. Eight (8) sectors of SMEs were identified for the analysis, with 60 SMEs chosen at random from each of these sectors. As a result, a total of 480 SMEs were selected for the study. Simple random sampling methods were used to distribute questionnaires to the 480 SMEs owners/managers that made up the study's sample size, and 392 copies of the questionnaires were collected for analyse. The distributions are shown in Table 1. SPSS version 25 was used to analyzed the data. The internal accuracy was checked using exploratory factor analysis with Kaiser-Meyer-Olkin (KMO) (see Table 2), while the effect of each of the five EO-dimensions on the business' competitive advantages was analyzed using multiple regression analysis.

\section{Exploratory Factor Analysis for the variables}

In survey research, the variables used are extensive and so there is a possibility that the effect of some of the variables will be directly related. A reduction is needed to ascertain any of the variables that are directly related. To achieve this, there is a need to find a cluster of related variables, which are easier to manage, and this is achieved through Exploratory Factor Analysis (EFA) (Ahadzie, 2007). The extent of relationships among all the measured variables to every factor is represented by a factor loading. A set of highly inter-correlated measured variables were grouped into distinct factors. EFA provides the researcher with information about the number of factors that best represent the data. In this study, twenty-seven items that measured EO were analysed. It is necessary that a data set to be analysed using EFA must pass suitability and reliability tests. As a result, the data were subjected to 
tests as required by EFA with the use of SPSS. The internal consistency test was conducted using the KaiserMeyer-Olkin (KMO) measure of sample adequacy and Bartlett test of sphericity (See Table 2). The result of the tests presented in Table 2 shows that the KMO value was 0.843 , which exceeded the recommended value of 0.700 (Cornish, 2007). This indicates that more than $84 \%$ of the variance in the measured variables is common variance. The Bartlett's test of sphericity value from the data set was statistically significant (chi-square with degrees of freedom $351=6949.448, \mathrm{P}=0.000$ ). This means that there were sufficient relationships among the variables to be investigated. The KMO and Bartlett's Test of sphericity values suggest that the data set in this study was suitable for EFA. Multi-collinearity test was also computed to measure the rate of inter-correlations among the independent variables. The result shows no multi-collinearity problem between the independent variables because the tolerance values were more than 0.10 and the VIF values were less than 10 (see Table 3 ).

Table 1: Questionnaires Distributed and Retrieved

\begin{tabular}{lllll}
\hline S/N & Sector & $\begin{array}{l}\text { Number of } \\
\text { distributed }\end{array}$ & $\begin{array}{l}\text { questionnaire } \\
\text { Number of questionnaire } \\
\text { retrieved }\end{array}$ & \%etrieved \\
\hline 1 & Real estate & 60 & 53 & 88 \\
2 & Furniture & 60 & 50 & 83 \\
3 & Agro business & 60 & 48 & 80 \\
4 & Hospitality & 60 & 50 & 83 \\
5 & Handcraft business & 60 & 44 & 73 \\
6 & Retail shops & 60 & 55 & 92 \\
7 & Consumers goods & 60 & 48 & 80 \\
8 & Factory marking & 60 & 44 & 73 \\
Total & $\mathbf{5 0 0}$ & $\mathbf{4 8 0}$ & $\mathbf{3 9 2}$ & $\mathbf{8 2}$ \\
\hline
\end{tabular}

Source: Field Survey, 2021

Table 2: KMO and Bartlett's Test EO data suitability

\begin{tabular}{ccc}
\hline Kaiser-Meyer-Olkin Measure of Sampling Adequacy & .843 \\
Bartlett's Test of Sphericity & Approx. Chi-square & 6949.448 \\
Df & & 351 \\
Sig. & .000 \\
\hline
\end{tabular}

Sources: Field Survey, 2021

\section{Results}

The regression coefficients of the independent variables on the firms' competitive advantages are seen in Table 3 . The results show that three of the independent variables (innovativeness, pro-activeness, and risk-taking had a positive relationship with the dependent variable (competitive advantages of the firms). This is an indication that an increase in these three variables will lead to an increase in the competitive advantages of the firms. From Table 3 , innovativeness has $(\beta=0.538, \mathrm{P}<0.000)$, pro-activeness $(\beta=0.239, \mathrm{P}<0.001)$ while risk-taking has $(\beta=0.064$, $\mathrm{P}<0.405)$. In a similar way, the negative sign in competitive aggressiveness and autonomy $(\beta=0.040, \mathrm{P}<0.589)$ and $(\beta=146, P<0.030)$, respectively, indicate that an increase in these two variables will lead to reduction effects on the competitive advantages of the firms. The regression results also show the $\mathrm{R}=0.789$, $\mathrm{R}$ - square $=0.615$, adjusted R-square of 0.602. The test of fitness of the regression is to estimate the effect of the EO variables on the competitive advantages of the firms and the analysis of variance (ANOVA) shows an F- value of 37.184 and significant value $\mathrm{P}<0.05 .61 .5 \%$ of the variance was taken to be explained by the regression line.

\section{Discussion}

The results of the study imply that out of the five EO-dimensions (innovativeness, pro-activeness, risk-taking competitive aggressiveness and autonomy) adopted in this study, three of them are significant with the performance, except for competitive aggressiveness and risk-taking. This implies that it is not necessary for employees to adopt a very competitive posture to combat trends that may threaten the survival of the business. Thus, employees do not need to undertake somewhat risky venture by committing resources to ventures with uncertain outcomes, since the adoption of the two independent variables (competitive aggressiveness and risktaking) have no improvement in the performance of the firms. This result is in line with previous studies by Gitau et al., (2016), Kuratko et al., (2001), Lechner and Gudmundsson (2014), Mohammend and Rusinah (2017), and Olowofeso (2021), which showed that firms' innovativeness had a substantial effect on their competitive advantages. Furthermore, the findings of this study are close to those of Baran and Velickaite (2008), who found that entrepreneurial orientation helped a company achieve development and prosperity, resulting in a long-term competitive advantage. According to Muchiri and McMurray (2015), companies that invest in entrepreneurial orientation outperform their counterparts that do not follow EO. According to Shahraki and Bahraini (2013), EO helps an organisation to respond to the external world by rapidly adjusting internal systems to satisfy the demands 
of the environment.

Table 3: Results of Regression Analysis: Effect of EO on Competitive Advantages of the Firms

\begin{tabular}{lllllll}
\multicolumn{3}{c}{$\begin{array}{l}\text { Unstandardized } \\
\text { Coefficients }\end{array}$} & & & & \multicolumn{2}{c}{$\begin{array}{c}\text { Collinearity Statistics } \\
\text { Model }\end{array}$} & $\mathrm{B}$ & Std. Error & $\mathrm{T}$ & $\mathrm{Sig}$ & Tolerance & VIF \\
\hline (Constant) & 1.543 & 0.273 & 5.651 & 0.000 & & 3.184 \\
INOV & $0.538^{* * *}$ & 0.100 & 5.364 & 0.000 & 0.314 & 2.601 \\
PROV & $0.239^{* * *}$ & 0.073 & 3.288 & 0.001 & 0.384 & 1.974 \\
COMA & -0.040 & 0.074 & -0.541 & 0.589 & 0.507 & 2.473 \\
RISK & 0.064 & 0.077 & 0.834 & 0.405 & 0.404 & 1.452 \\
AUTO & $-0.146^{* *}$ & 0.067 & -2.172 & 0.030 & 0.689 &
\end{tabular}

Model indices: $\mathrm{R}=0.789, \mathrm{R}^{2}=0.615$, Adjusted $\mathrm{R}^{2}=0.602, \mathrm{~F}$-Statistic $=37.184, \mathrm{P}$-value $=0.000$

** Significant at 5\% level

$* * *$ Significant at $1 \%$ level

Source: Field Survey, 2021

From Table 3, the model for the competitive advantages of the firms can be written as

$Y=a+\beta_{1} X_{1}+\beta_{2} X_{2}+\beta_{3} X_{3}+\beta_{4} X_{4}+\beta_{5} X_{5}+\ell_{i}$

$Y=a+\beta_{1}$ INOV $+\beta_{2}$ PROV $+\beta_{3}$ COMA $+\beta_{4}$ RISK $+\beta_{5}$ AUTO

Competitive advantages of the firm (Y)

$$
\begin{aligned}
& =1.543+0.538(\mathrm{INOV})+0.239(\mathrm{PROV})+(-0.040)(\mathrm{COMP})+0.064(\mathrm{RISK}) \\
& +(-0.146)(\text { AUTO })
\end{aligned}
$$

\section{Summary of the Hypotheses Testing}

This section presents the summary of hypotheses tested for this study. In the study, five hypotheses were formulated in the null form and tested using multiple regression analyses. Table 4 presents the summary findings of the hypotheses.

\begin{tabular}{|c|c|c|c|}
\hline $\mathbf{S} / \mathbf{N}$ & Research Hypotheses & Decision Results & \\
\hline 1 & $\begin{array}{l}\text { There is no significant effect of innovativeness on the competitive } \\
\text { advantages of SMEs. }\end{array}$ & $\begin{array}{l}\text { Null hypothesis } \\
\text { was rejected }\end{array}$ & $\left(\mathrm{H}_{01}\right)$ \\
\hline 2 & $\begin{array}{l}\text { There is no significant effect of pro-activeness on the competitive } \\
\text { advantages of SMEs. }\end{array}$ & $\begin{array}{l}\text { Null hypothesis } \\
\text { was rejected }\end{array}$ & $\left(\mathrm{H}_{02}\right)$ \\
\hline 3 & $\begin{array}{l}\text { There is no significant effect of risk-taking on the competitive advantages of } \\
\text { SMEs. }\end{array}$ & $\begin{array}{l}\text { Null hypothesis } \\
\text { was accepted }\end{array}$ & $\left(\mathrm{H}_{03}\right)$ \\
\hline 4 & $\begin{array}{l}\text { There is no significant effect of competitive aggressiveness on the } \\
\text { competitive advantages of SMEs. }\end{array}$ & $\begin{array}{l}\text { Null hypothesis } \\
\text { was accepted }\end{array}$ & $\left(\mathrm{H}_{04}\right)$ \\
\hline 5 & $\begin{array}{l}\text { There is no significant effect of autonomy on the competitive advantages of } \\
\text { SMEs. }\end{array}$ & $\begin{array}{l}\text { Null hypothesis } \\
\text { was rejected }\end{array}$ & $\left(\mathrm{H}_{05}\right)$ \\
\hline
\end{tabular}

Table 4: Summary Table of Hypotheses Tested

Source: Field Survey, 2021

\section{Conclusions and Recommendations}

The effect of EO on the competitive advantages of SMEs in the study area was empirically confirmed in this study. The study discovered a connection between the three EO-dimensions (innovativeness, proactiveness, and risktaking) and the firms' competitive advantages. It was also discovered that three of the EO-dimensions (innovativeness, proactiveness, and autonomy) were associated with the firms' competitive advantages. According to the findings, the factors that contribute to an increase in a firm's competitive advantages should be prioritized in market strategy. Workers may not need to follow a very aggressive posture to fight trends that may endanger the business's viability. Employees, thus, not need to undertake a somewhat risky venture by committing resources to ventures with uncertain outcomes since the adoption of the two independent variables (competitive aggressiveness and risk-taking) have no improvement in the performance of the firms.

\section{References}

Ahadzie, D. K., (2007). A model for predicting the performance of project managers in mass house building projects in Ghana. Unpublished Ph.D. thesis University of Wolverhampton, UK.

Alauddin, MD., \& Chowdhury, M. M. (2015). Small and medium scale enterprise in Bangladesh prospects and challenges. Global Journal of Management and Business Research: Finance, 15(7), 1-9.

Bangudu, O. (2013). Nigeria's operating environment for businesses has been difficult. Retrieved June 18, 2018, from http://www.premiumtimesng.com/business/145725. 
Baran, D., \& Velickaite, R. (2008). Building the theoretical framework of entrepreneurship Paper delivered at the fifth international scientific conference. Business and management held in Vilnius, Lithuania, 16-17 May.

Bateman, T. S., \& Snell, S. A. (2004). Management: The New Competitive Landscape. 6th ed. New York: McGraw Hill.

Casillas, J. C., \& Moreno, A. M. (2010). The relationship between entrepreneurial orientation and growth: The moderating role of family involvement. Entrepreneurship \& Regional Development, 22(3-4), 265-291.

Central Bank of Nigeria (2010). Business expectations survey. A Quarterly Publication of the Central Bank of Nigeria, 2nd Quarter.

Covin, J. G., \& Miller, D. (2014). International entrepreneurial orientation: Conceptual considerations, research themes, measurement issues, and future research directions. Entrepreneurship Theory and Practice, 38(1), 11-44.

Covin, J. G., \& Slevin, D. P. (1991). A conceptual model of entrepreneurship as firm behaviour, Entrepreneurship Theory and Practices, 16, 75.

Covin, J. G., \& Wales, W. J. (2012). The measurement of entrepreneurial orientation. Entrepreneurship Theory and Practice, 1(1), 1-26.

Dess, G. G., \& Lumpkin, G. T. (2005). The role of entrepreneurial orientation in stimulating effective corporate entrepreneurship. The Academy of Management Executive, 19(1), 147- 156.

Duke, J. E. (2006). Entrepreneurial strategy for the economic development of the Niger Delta Region of Nigeria: A study of selected projects/ organisations in the region. Unpublished Ph.D. thesis, University of Calabar.

Effiom, L., \& Edet, S. E. (2018). The success of small and medium enterprises in Nigeria: Do environmental factors matter. Journal of Economic and Sustainable Development, 9(4), 117-128.

Eniola, A. A. (2014). The role of SME firm performance in Nigeria. Arabian Journal of Business and Management Review 3(12) 33-47.

Etuk, R. U., Etuk, R. G., \& Baghebo, M. (2014). Small and medium scale enterprises (SMEs) and Nigeria's economic development. Mediterranean Journal of Social Sciences, 5(7) 656- 662.

Fauzul, M. F., Takenouchi, H., \& Yukiko, T. (2010). Entrepreneurial orientation and business performance of small and medium scale enterprises of Hambantota District Sri Lanka. Asian Social Sciences 6(3), 34-46.

Frese, M., Brantjes, A., \& Hoorn, R. (2002). Psychological success factors of small scale businesses in Namibia: The roles of the strategy process, entrepreneurial orientation and the environment. Journal of Developmental Entrepreneurship, 7(3), 259-282.

Gitau, G., Mukulu, E., \& Kihoro, J. (2016). Influence of entrepreneurial orientation on competitive advantage among mobile service providers in Kenya. International Journal of Management and Commerce Innovations, 3(2), 2010-2016.

Hoque, A. S., Siddiqui, B. A., Awang, Z., \& Baharu, S. M. (2018). Exploratory factor analysis of entrepreneurial orientation in the context of Bangladeshi small and medium enterprises (SMEs). European Journal of Management and Marketing Studies, 3(2), 81-94.

Hughes, M., \& Morgan, R. E. (2007). Deconstructing the relationship between entrepreneurial orientation and business performance at the embryonic stage of firm growth. Industrial Marketing Management, 36, 651661.

Huang, S. K., \& Wang, Y. L. (2011). Entrepreneurial orientation, learning orientation, and innovation in small and medium enterprises. Procedia - Social and Behavioral Sciences, 24, 563-570.

Kreiser, P. M., Marino, L. D., \& Wearver, K. M. (2002). Assessing the psychometric properties of Entrepreneurial orientation scale: A multi-country analysis. Entrepreneurship Theory and Practice 26(4), 71-94.

Kuratko, D. F., Ireland, R. D., \& Hornsby, J. S. (2001). Improving firm performance through entrepreneurial actions: Acordia's corporate entrepreneurship strategy. Academy of Management Executive, 15(4), 60-71.

Kusumawardhani, A. (2013). The role of entrepreneurial orientation in firm performance: A study of Indonesian SMEs in the furniture industry in Central Java. (Unpublished doctoral dissertation). University of Wollongong, Sydney Business School, Sydney, Australia.

Lechner, C., \& Gudmundsson, S. V. (2014). Entrepreneurial orientation, firm strategy and small firm performance. International Small Business Journal, 32(1), 36-60.

Li, Y. H, Huang, J. W., \& Tsai, M. T. (2009). Entrepreneurial orientation and firm performance: The role of knowledge creation process. Industrial Marketing Management, 38(4), 440-449.

Lumpkin, G. T., \& Dess, G. G. (1996). Clarifying the entrepreneurial orientation construct \& linking it to performance. Academy of Management Review, 21(1), 135-172.

Lyon, D. W., Lumpkin, G. T., \& Dess, G. G. (2000). Enhancing entrepreneurial orientation research: Operationalizing and measuring a key strategic decision-making process. Journal of Management, 26(5), $1055-1085$

Masika, A. M. (2010). Factors influencing real estate property prices. A Survey of real estate in Meru Municipality, Kenya. Kenya Methodist University, Meru. 
Miller, D. (1983). The correlates of entrepreneurship in three types of firms. Management Science, 29(7), $770-791$.

Miller, D. (2011). A reflection on entrepreneurial orientation research and some suggestions for the future. Entrepreneurship Theory and Practice, 35(6), 873-894.

Mohammed, R. Y. Z., \& Rusinah, B. (2017). The impact of entrepreneurial orientation on competitive advantage moderated by financing support in SMEs. International Review of Management and Marketing 7(1), 43-52.

National Bureau of Statistics NBS. (2015). 'Nigerian real estate sector, Summary Report 2010- 2012'2015 Real Estate outlook in Nigeria, February.

Obaji, N. O., \& Olugu, M. U. (2014). The role of Government policy in entrepreneurship development. Science Journal of Business and Management, 2(4), 109-115.

Olowofeso, E. (2021). Analysis of entrepreneurial orientation on the performance of real estate firms in South West, Nigeria. Unpublished Ph.D. thesis, Department of Project Management, The Federal University of Technology, Akure.

Olubiyi, T. O., Egwakhe, A. J., Amos, B., \& Ajayi, A. A. (2019). Entrepreneurial orientation and firm profitability: Evidence from Lagos State Nigeria. Journal of Business and Management, 2(6), $42-54$.

Porter, M. E. (1990). Strategy and society. The link between competitive advantage and corporate social responsibility. Harvard Business Review, 84, 78-92.

Rauch, A., Wiklund, J., Frese, M., \& Lumpkin, G. T. (2005). Entrepreneurial orientation and business performance: Cumulative Empirical evidence. The $23^{\text {rd }}$ Babson College Entrepreneurship research conference. Glasgow, UK. 2008: Paper presented at the $23^{\text {rd }}$ Babson College Entrepreneurship research conference.

Rauch, A., Wiklund, J., Lumpkin, G. T., \& Frese, M. (2009). Entrepreneurial orientation and business performance: An assessment of past research and suggestions for the future. Entrepreneurship Theory and Practice, 33(3), 761-787.

Rosenbusch, N., Rauch, A., \& Bausch, A. (2013). The mediating role of entrepreneurial orientation in the task environment-performance relationship: A meta-analysis. Journal of Management, 39(3), 633-659.

Shahraki, M. R., \& Bahraini, Z. (2013). An examination of the relationship between transformational leadership with entrepreneurial orientation in organisation (Case Study: Mobin Petrochemical Company- South Pars). International Journal of Advanced Studies in Humanities and Social Science, 1(4), 274-289.

Thompson, J. L. (2001), Strategy Management. 5th ed. London: Thomsom Learning.

Tovstiga, G., \& Tulugurova, E. (2009). Intellectual capital practices: a four-region comparative study. Journal of Intellectual Capital, 10(1), 70-80.

Van- Geenhuizen, M., Middel, R., \& Lassen, A. H. (2008). Corporate entrepreneurship in SMEs during the search for discontinuous innovations. In 9th International CINet Conference: Radical Challenges in Innovation Management.

Wales, W. J., Gupta, V. K., \& Mousa, F. T. (2011). Empirical research on entrepreneurial orientation: An assessment and suggestions for future research. International Small Business Journal, 3(4), 357-383.

Walter, A., Auer, M., \& Ritter, T. (2006). The impact of network capabilities and entrepreneurial orientation on university spin-off performance. Journal of Business Venturing, 21(4), 541-567.

Wiklund, J., \& Shepherd, D. (2003). Knowledge-based resources, entrepreneurial orientation, and the performance of small and medium-sized businesses. Strategic Management Journal, 24(13), 1307-1314.

Yamada, K. K., \& Eshima, Y. (2009). Impact of entrepreneurial orientation: Longitudinal analysis of small technology firms in Japan. Academy of management proceedings, 1(1), 1-11. 